\title{
Senior High School Learning Motivation on Physics Subject
}

\author{
Nurmalita Sari \\ Widha Sunarno \\ Sarwanto \\ Master's on Science Education, Sebelas Maret University Surakarta \\ nurmalita33@gmail.com
}

\begin{abstract}
Learning motivation is students' willingness to study that comes from within. The objective of this research was to find out Senior High School students' learning motivation level for physics subject. The subjects of this research were 60 students from Science Class of Senior High School 5 Surakarta who were randomly selected. A questionnaire was used as an instrument to measure students' learning motivation. The result showed that students' learning motivation in physics subject was categorized as medium level with an average score of 20.42. The percentage for each aspect was as follows: attention $(24.33 \%)$, relevance $(24.98 \%)$, confidence $(24.33 \%)$, and satisfaction $(25.71 \%)$.
\end{abstract}

Keywords: ARCS, learning, motivation, physics

\begin{abstract}
Abstrak: Motivasi belajar merupakan daya dorong dari dalam diri siswa untuk belajar. Penelitian ini bertujuan untuk mengetahui tingkat motivasi belajar siswa Sekolah Menengah Atas untuk mata pelajaran fisika. Penelitian dilaksanakan di SMA Negeri 5 Surakarta dengan subyek penelitian sebanyak 60 siswa jurusan MIPA yang dipilih secara random. Instrumen penelitian yang digunakan untuk mengukur motivasi belajar adalah angket. Angket motivasi dikembangkan berdasarkan aspek ARCS (Attention, Relevance, Confidence, Satisfaction). Berdasarkan hasil penelitian, tingkat motivasi belajar siswa untuk mata pelajaran fisika termasuk kategori sedang dengan rata-rata 20,42. Persentase dari masing-masing aspek motivasi belajar adalah Attention/perhatian (24,33\%), Relevance/relevansi (24,98\%), Confidence/percaya diri (24,33\%) dan Satisfaction/kepuasan (25,71\%).
\end{abstract}

Kata kunci: ARCS, belajar, fisika, motivasi

Physics belongs to a group of science subjects that examine the physical aspects of the human environment and it is related to the phenomenon in everyday life. The principle of science learning is putting forward the scientific process to produce products based on scientific attitude. The scientific process in physics learning is identical to the activity in the scientific method. The resulting product is not only shaped objects but focuses on an idea or scientific thinking. A scientific attitude will be formed through a scientific process.

Education is identical to the learning process. Learning is a process of change within the individual that generates behavioral changes because of the interaction results of others and the environment based on certain practices and experiences (Uno, 2008). The success of a student's learning process is influenced by numerous factors, internal and external. Slameto (2010) explains the factors that influence the student's learning process is internal factors including physical factors, psychological factors (intelligence, attention, interest, talent, motivation, maturity and readiness) and tiredness factors. External factors that influence, among others, family factors, school factors (teaching methods teachers, school curriculum, school environment) and community factors.

Motivation is one of the internal factors which influences student's learning motivation. Motivation is derived from the word "motive". It means all the attempts and efforts that drive someone to act to do something. Motives can be considered as the driving force from within the individual to perform certain activities in order to achieve a goal. Motivation is one of the factors that affect the action which is taken by an individual (Sardiman, 2007). Uno (2008) limits the essence of learning motivation as an internal and external motivation of students who are 
engaging in a learning activity as a form of behavioral changing. According to several definitions suggested by soe scholars, it can be concluded that learning motivation is the entire forces and attempts within students which encourage them to engage in learning, ensure the process of learning activity, and provide direction on learning activity in order to achieve learning goal. Besides from within students' internal encouragement, learning motivation could arise from learning environment. A research conducted by Cicuto and Torres (2016) suggest that active learning environment could motivate students to study hard. In addition, active learning environment is supported by active learning procress.

A research conducted by Velayutham, Aldridge, and Fraser (2011) explain the importance of knowing the degree of students' learning motivation on science subject. Initial challenge for a teacher is activating students' learning motivation on science subject. Students' learning motivation on science subject is an imperative affective component since it underlie the process of conceptualizing certain material, critical thinking, learning strategy, and learning accomplishment. The notion is further strengthened by Fyan and Maehr's research result (Budiawan and Arsani, 2013). The result explains that there are three factors influencing students' learning outcome such as family background, school condition or context, and motivation. It concludes that the last factor, motivation, takes a paramount effect on students' learning outcome.

Keller (1987) develops aspects which can be used to measure the degree of studens' learning motivation called ARCS. ARCS developed by Keller is in accordance with the synthesis from motivation concept and motivation characteristics and it is classified as four aspects namely Attention, Relevance, Confidence, and Satisfaction. Each aspect is explained in the following Table 1.

Table 1. Learning Motivation Aspect

\begin{tabular}{ll}
\hline $\begin{array}{c}\text { Motivation } \\
\text { Aspect }\end{array}$ & \multicolumn{1}{c}{ Description } \\
\hline Attention & $\begin{array}{l}\text { Attitude shown by students by } \\
\text { giving attention on Physics lesson }\end{array}$ \\
\hline Relevance & $\begin{array}{l}\text { Student's perspective of the cor- } \\
\text { relation between benefits and its } \\
\text { application to everyday life }\end{array}$ \\
\hline
\end{tabular}

\begin{tabular}{ll}
\hline $\begin{array}{c}\text { Motivation } \\
\text { Aspect }\end{array}$ & \multicolumn{1}{c}{ Description } \\
\hline Confidence & $\begin{array}{l}\text { Students' self-confidence in Phys- } \\
\text { ics lesson and solving Physics } \\
\text { problems }\end{array}$ \\
\hline Satisfaction & $\begin{array}{l}\text { A sense of satisfaction from } \\
\text { within students in solving Physics } \\
\text { problems }\end{array}$ \\
\hline Source: Keller (1987) &
\end{tabular}

This present paper aims at determining senior high school students' learning motivation profile on Physics subject. The authors expect that the result of this research could reveal the degree of senior high school students' learning motivation which is classified as high, moderate, and low. Further, it is expected that the result of this research could provide Physics teacher or education practitioner a framework for evaluating Physics learning in school.

\section{METHOD}

This research is a survey research. The authors utilized purposive technique to determine the location of the research, SMA Negeri 5 surakarta. The population of this research is the entire first, second, and third graders of Science Class at SMA Negeri 5 Surakarta. The determination of research sample was based on Sugiyono's opinion (2009) stating that if the population number is less than 100 , the population could be taken as a sample. However, if the population is more than 100 , the sample for the research should consist of $10 \%-15 \%$ from the entire population. The number of population as a research subject in SMA Negeri 5 Surakarta is 450 . Then, the sample taken was 60 students of Science Class from first, second, and third graders which were chosen randomly.

The instrument for collecting the data was used learning motivation questionnaire which was arranged in accordance with ARCS motivation aspects. Learning motivation indicators which were measured based on ARCS motivation aspects is presented in Table 2 . 
Table 2. Learning Motivation Indicators

\begin{tabular}{|c|c|c|}
\hline No & $\begin{array}{l}\text { Motivation } \\
\text { Aspect }\end{array}$ & Description \\
\hline \multirow[t]{2}{*}{1.} & Attention & $\begin{array}{l}\text { Being attentive during the learn- } \\
\text { ing process }\end{array}$ \\
\hline & & $\begin{array}{l}\text { Being active in giving questions, } \\
\text { if they find a difficulty }\end{array}$ \\
\hline \multirow[t]{2}{*}{2.} & Relevance & $\begin{array}{l}\text { Able to relate the one theory to } \\
\text { the other theory of Physics }\end{array}$ \\
\hline & & $\begin{array}{l}\text { Able to explain its application to } \\
\text { daily life }\end{array}$ \\
\hline \multirow[t]{2}{*}{3.} & Confidence & $\begin{array}{l}\text { Able to express the opinion or } \\
\text { answer the question }\end{array}$ \\
\hline & & $\begin{array}{l}\text { Able to solve the problems } \\
\text { independently }\end{array}$ \\
\hline \multirow[t]{2}{*}{4.} & Satisfaction & Being active with the peers \\
\hline & & $\begin{array}{l}\text { Able to accomplish the assign- } \\
\text { ment }\end{array}$ \\
\hline
\end{tabular}

The method of scoring the questionnaire of student learning motivation was based on Likert scale with 4 answer choices. Choice of answers provided for questionnaire motivation to learn are $4=$ always, $3=$ sometimes, $2=$ rare, $1=$ never. Techniques of data analysis motivation to learn was done by accumulating scores of each item number questionnaire then grouped in the category of high, average, and low motivation. The next step was to find the percentage (\%) of each learning motivation category. The criteria for classifying the learning motivation categories for each student are presented in Table 3.

Table 3. Students' Learning Motivation Category

\begin{tabular}{ll}
\hline Score $(\mathrm{X})$ & Criteria \\
\hline$x \geq \bar{X}+S D$ & High \\
\hline $\bar{X}-S D \leq X<\bar{X}+S D$ & Average \\
\hline$X<\bar{X}-S D$ & Low \\
\hline
\end{tabular}

Sumber: Arikunto (2008)

Remarks:

$X \quad$ : Students' learning motivation score

$\bar{X}$ : Students' learning motivation score average

$S D$ : Students' learning motivation score standard deviation

\section{RESULTS AND DISCUSSIONS}

\section{Result}

The result of this research indicates that the average score of students' learning motivation from 60 students is 20.42 . The standard deviation from students' learning motivation of the entire sample is 4.01. Both average score and standard deviation of students' learning motivation are used to classified students' learning motivation on Physics subject. According to the average score and the standard deviation, students' learning motivation on Physics subject can be seen in the following Table 4 .

\section{Table 4. Students' Learning Motivation Classification on Physics Subject}

\begin{tabular}{ll}
\hline Score $(X)$ & Criteria \\
\hline$X \geq 24,42$ & High \\
\hline $16,41 \leq X<24,42$ & Average \\
\hline$X<16,41$ & Low \\
\hline
\end{tabular}

Scoring method on students' learning motivation was according to Likert scale with the four options of answers. The answers option provided for students' learning motivation questionnaire are 4 means always, 3 means often, 2 means rarely, and 1 means never. The data analysis of students' learning motivation was conducted by accumulating score from each point in the questionnaire and then it was classified as high learning motivation, moderate learning motivation, and low learning motivation. The next step was calculating the percentage (\%) of each learning motivation classification. The criteria of students' learning motivation classification is presented in Table 3.

The total score from the answers of the learning motivation questionnaire completed by the students was then cohered with motivation degree criteria in Table 4. The data analysis results of students' learning motivation questionnaire on Physics subject is presented in the following Table 5. 
Table 5. Results of Physics Learning Motivation Data Analysis

\begin{tabular}{lll}
\hline Motivation & $\begin{array}{c}\text { Total } \\
\text { Students }\end{array}$ & $\begin{array}{c}\text { Percentage } \\
\text { (\%) }\end{array}$ \\
\hline High & 8 & 13,33 \\
\hline Average & 46 & 76,67 \\
\hline Low & 8 & 13,33 \\
\hline
\end{tabular}

The results of the analysis of the questionnaire and the percentage of the number of students who fell into the category of high, moderate, low were used to determine the profile of students' learning motivation during the Physics subject learning.

According to the results from Table 4 and Table 5 , it can be concluded that the students' learning motivation degree for Physics subject is in moderate classification with average Physics subject learning motivation of 20.42. The students who were included in the moderate learning motivation classification while attending Physics lessons were $76.67 \%$. Students' learning motivation on Physics subject which was included in the high classification were only eight students with a percentage of $13.33 \%$. The level of students' learning motivation in studying Physics subject who were included in the low classification were also eight students with a percentage of $13.33 \%$.

Students' learning motivation on Physics subject was measured based on ARCS aspects. The percentage of each measured aspect is presented in the following Figure 1.

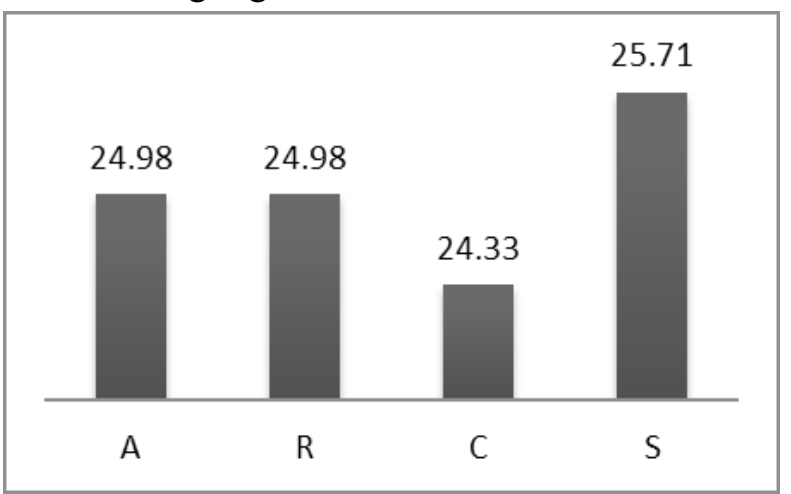

Figure 1. Percentage of Learning Motivation ARCS

According to Figure 1, it indicates that the highest aspect of students' learning motivation on Physics subject is Satisfaction with a percentage of $25.71 \%$. Then, it is followed by Attention aspect and Relevance aspect with the same percentage of
24.98\%. The aspect of confidence takes the least position with a percentage of $24.33 \%$.

\section{Discussion}

Motivation to learn is an attempt in students to learn and follow the learning process. The average of student's learning motivation for Physics subject from the research result is 20,42 and included in moderate classification. There are 46 students from 60 students as research samples who have moderate learning motivation.

Learning motivation is the form of driving force in students in learning Physics as an important subject of science to be understood. Velayutham, Aldridge, \& Fraser (2011) conducted research on background in knowing students' learning motivation of science learning. Science learning motivation underlies the process of conceptualizing a material, critical thinking, learning strategy, and learning accomplishment.

ARCS aspects were used to determine the students' learning motivation on Physics subject. According to the research results, it is indicated that satisfaction is the highest aspect with the percentage of $25.71 \%$. Satisfaction aspect indicator is seen from students' attempt in being active during the learning or managing to be predominated from the other peers as well as the attempt of students in completing the assignments and exams. If the percentage aspect of Satisfaction equal to $25,71 \%$ and its indicator are linked, it can be concluded that in Physics subject learning student have willingness or impetus to solve all problem related to Physics subject. In addition, students also have a desire to play an active role or be more prominent than other friends during Physics learning in the classroom. The lowest aspect of students' learning motivation is confidence. The percentage of confidence is $24.33 \%$. In this context, confidence is self-confidence during the process of Physics subject learning and the way the students solve all problems related to Physics. According to the indicators presented in Table 2, the lowest percentage of aspects is. It can be described that the students lack the confidence during Physics learning. Weak confidence is seen from the lack of awareness of students to solve problems related to Physics subject independently. Students are also less likely to convey ideas or opinions related to Physics issues.

Both Attention and Relevance aspects have similar percentage, $24.98 \%$. In this context, attention is a form of attention provided by students during Physics subject learning in the classroom. The degree 
of attention provided by students is seen from the willingness of students in taking notes during the larning, paying an attention to the Physics teacher, and having a courage to ask a question to the teacher if they found a difficulty.

Then, relevance aspect is related to the students' awareness on the importance of Physics in their daily life of the relvance of Physics regarding the phenomena occured in their daily life. In addition, the relevance is related to students' ability to correlate previous Physics topics with the other. Relevance aspect is important for students in order to make students understand the benefit of learning science, particularly Physics.

This results are strengthened by Indah, Sunarno, and Sarwanto (2016) research which measure the degree of sudents' learning motivation using ARCS aspects. It obtained the average of $34 \%$ from the four measured ARCS aspects. It futher fall into moderate learning motivation.

Physics subject is identical with studying physical concepts accompanied by mathematical equations. Both of these require concurrent understanding within the student. Students' motivation on Physics subject learning from research results which included in moderate classification is not in line with the result of research from Samsudin, et. al. (2012) that the students' motivation to study Physics subject fell into low classification. The low classification is indicted by the average score of the students' motivation which was only 60.2 . In addition, the results explained that aspects of attention and confidence of students in solving physics problems have the lowest percentage. Sari, et. al (2015) revealed that the motivation of learning within the students in the Physics subject can affect learning achievement or cognitive results. Students with low learning motivation have low cognitive learning outcomes for static fluid materials.

Students' learning motivation in science is influenced by factors from the students and the teacher (Hynd, et. al., 2000). Factors derived from the students are the interest and passion of students to study science subjects. Factors from the teachers which influence students' learning motivation are the curriculum, the interaction of teachers with students and the model of learning applied by teachers. Physical learning that is included in science can be implemented by taking into account the use of instructional model applied by the teacher. In addition, learning media can also affect the passion of students in Physics subject learning. Research from
Piraksa \& Srisawasdi (2014) involving 66 students of Second Gradersof Science in a Secondary School in Thailand, show that the application of guided inquiry model combined with virtual laboratory can improve students' learning motivation in Physics subject learning.

The degree of learning motivation of one student can influence the other. It is proven by Cicuto and Torres (2016) research which states that active learning environment could encourage student's motivation to study hard. Active learning environment is also supported by active learning process. Active learning environment is activated by students during learning process.

\section{CONCLUSION AND SUGGESTIONS}

This research concludes that the degree of students' learning motivation on Physics subject fall into moderate classification. The average of students' learning motivation on Physics subject is 20.42 . Students' learning motivation was measured from Attention, Relevance, Confidence, and Satisfaction aspects. The percentage of each aspect is Attention equal to $24,33 \%$, Relevance equal to $24,98 \%$, Confidence equal to $24,33 \%$ and Satisfaction equal to $25,71 \%$.

Students' learning motivation is a driving force within the individual during Physics subject learning. The degree of learning motivation in student influences student's learning achievement. Therefore, it is important for students to have an awareness to study Physics sinc it is correlated with the existing phenomena in their daily life. In addition, other factor which is available to encourage the students in learning Physics is learning model, learning media, school environment, and the curriculum.

\section{REFERENCES}

Arikunto, S. 2008. Prosedur Penelitian (Edisi Revisi). Jakarta: Rineka Cipta.

Budiawan, M., \& Arsani, N.L. 2013. Pengaruh Model Pembelajaran Kooperatif Tipe Jigsaw dan Motivasi Belajar Terhadap Prestasi Belajar Ilmu Fisiologi Olahraga. Jurnal Pendidikan Indonesia, 2(1): 138-144.

Cicuto, C. A. T., \& Torres, B. B. 2016. Implementing an Active Learning Environment to Influence Students' Motivation in Biochemistry. Journal of Chemical Education, 93(6): 1020-1026.

Hynd, C., Holschuh, J., \& Nist, S. 2000. Learning Complex Scientific Information: Motivation Theory and Its Relation to Student Perceptions. Reading and Writing Quarterly, 16(1): 23-57.

Indah, D. S., Sunarno, W., \& Sarwanto. 2016. 
Pengembangan Modul Fisika Berbasis Savi (Somatic, Auditory, Visualization, Intellectually) untuk Meningkatkan Motivasi Siswa pada Pembelajaran Fisika Kelas X SMK Jurusan Multimedia dengan Topik Impuls dan Momentum. Tesis tidak diterbitkan. Surakarta: PPS UNS Surakarta.

Keller, J. M. 1987. Development and Use of the ARCS Model of Instructional Design. Journal of Instructional Development, 10(3): 2-10.

Piraksa, C., Srisawasdi, N. 2014. Promoting Student's Physics Motivation by Blended Combination of Physical and Virtual Laboratory Environment: A Result on Different Levels of Inquiry. Makalah disajikan dalam acara Proceeding of the $22^{\text {nd }}$ International Conference on Computers in Education, Jepang, 3-5 November.

Samsudin, A., Suhendi, E., Efendi, R., \& Suhandi, A. 2012. Pengembangan "CELS" Dalam Eksperimen Fisika Dasar untuk Mengembangkan Performance Skills dan Meningkatkan Motivasi
Belajar Mahasiswa. Jurnal Pendidikan Fisika Indonesia, 8(1): 15-25.

Sardiman. 2007. Interaksi dan Motivasi Belajar Mengajar. Jakarta: PT. Raja Grafindo Persada.

Sari, N., Jamzuri, \& Rahmasari, L. 2015. Pengaruh Pembelajaran Kooperatif Model STAD dan Think Pair Share terhadap Kemampuan Kognitif Ditinjau dari Motivasi Siswa Kelas X SMAN 6 Surakarta. Skripsi tidak dipublikasikan. Surakarta: FKIP UNS Surakarta.

Slameto. 2010. Belajar dan Faktor-faktor yang Mempengaruhinya. Jakarta: Rineka Cipta.

Sugiyono. 2009. Metode Penelitian Kualitatif, Kuantitatif dan $R \& D$. Bandung: Alfabeta.

Uno, H. B. 2008. Teori Motivasi \& Pengukurannya. Jakarta: Bumi Aksara.

Velayutham, S., Aldridge, J., \& Fraser, B. 2011. Development and Validation of an Instrument to Measure Students' Motivation and Self Regulation in Science Learning. International Journal of Science Education, 33(15): 21592179 . 